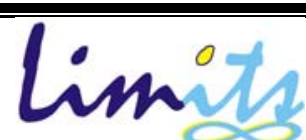

Limits: Journal of Mathematics and Its Applications

E-ISSN: 2579-8936

P-ISSN: $1829-605 \mathrm{X}$

Vol. 17, No. 1, Juli 2020, 19-33

DOI: http://dx.doi.org/10.12962/limits.v17i1.6809

\title{
Bifurkasi Periode Ganda dan Neimark-Sacker pada Model Diskret Leslie-Gower dengan Fungsi Respon Ratio-Dependent
}

\author{
Reza Mokodompit ${ }^{1}$, Nurwan ${ }^{2}$, Emli Rahmi ${ }^{3, *}$ \\ 1,2,3 Jurusan Matematika, Universitas Negeri Gorontalo, Gorontalo, Indonesia \\ e-mail: emlirahmi@ung.ac.id
}

Diajukan:16 April 2020, Diperbaiki: 3 Juni 2020, Diterima:17 Juni 2020

\begin{abstract}
Abstrak
Dinamika model Leslie-Gower dengan fungsi respon ratio-dependent yang didiskretisasi menggunakan skema Euler maju adalah fokus utama pada artikel ini. Analisis diawali dengan mengidentifikasi eksistensi dari titik ekuilibrium dan kestabilan lokalnya. Diperoleh empat titik ekuilibrium yaitu titik kepunahan kedua populasi dan titik kepunahan predator yang selalu tidak stabil, dan titik kepunahan prey dan eksistensi kedua populasi yang stabil kondisional. Selanjutnya dipelajari eksistensi dari bifurkasi periode ganda dan Neimark-Sacker di sekitar titik eksistensi kedua populasi sebagai akibat perubahan parameter $h$ (time-step). Dari hasil analisis ditemukan bahwa bifurkasi periode ganda terjadi setelah melewati $h=h_{a}$ atau $h=h_{c}$ dan bifurkasi Neimark-Sacker terjadi setelah melewati $h=h_{b}$. Di akhir pembahasan, diberikan simulasi numerik yang mendukung hasil analisis sebelumnya.
\end{abstract}

Kata Kunci: model predator-prey, Leslie-Gower, proses diskretisasi, bifurkasi.

\begin{abstract}
In this paper, the dynamics of discrete Leslie-Gower model with ratio-dependent functional response constructed by forward Euler scheme is studied. Firstly, we identify the existence of equilibrium points and their local stability. We obtain four equilibrium points i.e the extinction point of both population and the predator extinction point which are always unstable, the prey extinction point and co-existence point which are conditionally locally stable. Furthermore, the existence of period-doubling and Neimark-Sacker bifurcation are investigated driven by time-step size parameter (h). It is shown that the period-doubling bifurcation occurs when $h$ passes through $h_{a}$ or $h_{c}$ and Neimark-Sacker bifurcation occurs when $h$ passes through $h_{b}$. We end our result by present some numerical simulations which support previous analytical results.
\end{abstract}

Keywords: predator-prey model, Leslie-Gower, discretization process, bifurcation.

\section{Pendahuluan}

Dinamika model predator dan prey telah menjadi salah satu topik penting dalam matematika ekologi karena keberadaannya dalam interaksi antar makhluk di alam semesta [1]. Pada tahun 1926, untuk pertama kalinya Lotka dan Volterra secara terpisah memperkenalkan suatu model predator-prey sederhana yang dikenal dengan model Lotka-Volterra [2]. Model Lotka-Volterra mengasumsikan bahwa predator dan prey tumbuh secara eksponensial. Untuk memperbaiki asumsi ini, tahun 1948 Leslie dan Gower melakukan modifikasi pada model Lotka-Volterra yang 
dikenal dengan model Leslie-Gower [3]. Pada model Leslie-Gower kedua populasi diasumsikan tumbuh secara logistik dimana daya dukung predator sebanding dengan kepadatan prey. Namun mengingat bahwa prey tidak tersedia dalam jumlah melimpah di alam maka Aziz-Alaoui dan Okiye memodifikasi model Leslie-Gower dengan mengasumsikan adanya mangsa lain selain prey ketika kepadatan prey cukup rendah [4].

Dalam interaksi antara predator dan prey, proses pemangsaan predator terhadap prey dinyatakan oleh fungsi respon predator [2]. Holling [5], memperkenalkan fungsi respon yang hanya bergantung pada ketersediaan prey saja yang disebut prey-dependent. Lebih lanjut, Arditi dan Ginzburg [6] memperkenalkan fungsi respon yang bergantung pada rasio prey terhadap predator yang disebut ratio-dependent. Beberapa penelitian tentang model predator-prey dengan fungsi respon ratio-dependent seperti yang dilakukan di [6]-[9] menunjukkan bahwa fungsi respon ratio-dependent sangat sesuai dengan kondisi dimana predator membutuhkan waktu untuk mencari dan mencerna prey-nya.

Kajian tentang model predator-prey terus berkembang dengan menambahkan berbagai asumsi yg membuat model semakin realistis dan kompleks seperti adanya pemanenan pada predator [10]-[12], adanya efek Allee pada predator [13], [14], infeksi penyakit pada prey [15], dan sebagainya. Hal ini menyebabkan solusi tidak dapat ditentukan secara analitik, sehingga dibutuhkan pendekatan secara numerik. Salah satu pendekatan numerik yang dapat dilakukan untuk mencari solusi dari model kontinu adalah dengan melakukan diskretisasi terhadap model tersebut. Proses diskretisasi ini akan menghasilkan model diskret yang dapat mendekati solusi dari model kontinu. Hasil kajian di [16] dan [17] pada model diskret Lotka-Volterra menunjukkan bahwa dinamika model diskret lebih kaya jika dibandingkan dengan model kontinu.

\section{Metode Penelitian}

Adapun tahapan-tahapan dan prosedur analisis yang dilakukan dalam penelitian ini adalah sebagai berikut.

\subsection{Menentukan Model}

Aziz-Alaoui dan Okiye [4] mengkaji keterbatasan solusi dan kestabilan global model LeslieGower dengan fungsi respon Holling tipe II sebagai berikut:

$$
\begin{aligned}
& \frac{d x}{d t}=\left(r-b_{1} x-\frac{\mu y}{x+\beta}\right) x \\
& \frac{d y}{d t}=\left(\xi-\frac{k y}{x+\delta}\right) y
\end{aligned}
$$


dengan $x(0) \geq 0$ dan $y(0) \geq 0, x$ dan $y$ masing-masing menyatakan kepadatan populasi prey dan predator pada saat $t ; r, b_{1}, \mu, \beta, \xi, k$, dan $\delta$ adalah parameter-parameter yang bernilai positif. Parameter tersebut didefinisikan sebagai berikut: $r$ dan $\xi$ masing-masing menyatakan laju pertumbuhan intrinsik prey dan predator, $b_{1}$ adalah parameter yang mengukur kompetisi yang terjadi antar prey, $\mu$ adalah nilai maksimum yang dapat dicapai oleh laju reduksi per kapita $x$ ketika dimangsa $y, k$ adalah nilai maksimum yang dapat dicapai oleh laju reduksi per kapita $y$ sebagai akibat kompetisi antar predator, dan $\beta, \delta$ berturut-turut menyatakan besarnya perlindungan yang diberikan oleh lingkungan terhadap $x$ dan $y$.

Fungsi respon predator yang digunakan pada persamaan (1) adalah fungsi respon Holling tipe II yang prey-dependent, yaitu $p(x)=\frac{\mu x}{x+\beta}$. Dengan mengasumsikan bahwa rasio kepadatan populasi prey dan predator berpengaruh ketika pemangsaan terjadi seperti yang diajukan oleh Arditi dan Ginzburg [6] maka bentuk fungsi respon ratio-dependent yang mengikuti Holling tipe II adalah $p\left(\frac{x}{y}\right)=\frac{\mu x}{x+\beta y}$.

Pilih $b_{1}=\frac{r}{K}, k=\frac{1}{\eta}, \alpha=\eta \delta$ dan dengan menggunakan fungsi respon ratio-dependent, maka persamaan (1) menjadi:

$$
\begin{aligned}
& \frac{d x}{d t}=r x\left(1-\frac{x}{K}\right)-\frac{\mu x y}{x+\beta y} \\
& \frac{d y}{d t}=\xi y\left(1-\frac{y}{\eta x+\alpha}\right)
\end{aligned}
$$

Model pada persamaan (2) adalah model Leslie-Gower dengan fungsi respon ratio-dependent.

\subsection{Non-Dimensionalisasi}

Sebelum didiskretisasi, terlebih dahulu dilakukan non-dimensionalisasi terhadap model pada persamaan (2). Non-dimensionalisasi model akan memangkas beberapa parameter sehingga memudahkan proses analisis. Non-dimensionalisasi dapat dilakukan karena tidak mengubah kualitatif model [18], [19].

Dengan memilih $(x, y, t) \rightarrow\left(\frac{1}{K} x, \frac{\beta}{K} y, r t\right)$, diperoleh model non-dimensional dari model pada persamaan (2) sebagai berikut.

$$
\begin{aligned}
& \frac{d x}{d t}=x(1-x)-\frac{m x y}{x+y}, \\
& \frac{d y}{d t}=s y\left(1-\frac{b y}{x+a}\right)
\end{aligned}
$$


dengan $m=\frac{\mu}{\beta r}, s=\frac{\xi}{r}, b=\frac{1}{\beta \eta}, a=\frac{\alpha}{\eta K}$, dan $\alpha, \beta, \eta, \mu, \xi, r, K>0$. Model diskret dari model pada persamaan (3) adalah model yang akan dikaji dalam artikel ini.

\subsection{Analisis Model Diskret}

Analisis model pada persamaan (3) menggunakan definisi dan dua lemma berikut.

Definisi 1. [20] Suatu titik $\hat{x}$ yang berada dalam domain $f$ dikatakan sebagai titik ekulibrium dari suatu persamaan beda $x_{n+1}=f\left(x_{n}\right)$ jika $f(\hat{x})=\hat{x}$.

Lemma 2. [21] Misalkan $\lambda_{1}$ dan $\lambda_{2}$ adalah nilai-nilai eigen dari matriks Jacobi $D f(\hat{x})$ sehingga:

(i) Jika $\left|\lambda_{1}\right|<1$ dan $\left|\lambda_{2}\right|<1$, maka titik ekuilibrium dari $D f(\hat{x})$ stabil asimtotik lokal (sink).

(ii) Jika $\left|\lambda_{1}\right|>1$ dan $\left|\lambda_{2}\right|>1$, maka titik ekuilibrium dari $D f(\hat{x})$ tidak stabil (source).

(iii) Jika $\left|\lambda_{1}\right|<1$ dan $\left|\lambda_{2}\right|>1$ (atau, $\left|\lambda_{1}\right|>1$ dan $\left|\lambda_{2}\right|<1$ ), maka titik ekuilibrium dari $D f(\hat{x})$ tidak stabil (saddle).

(iv) Jika $\left|\lambda_{1}\right|=1$ atau $\left|\lambda_{2}\right|=1$, maka titik kesetimbangan dari $D f(\hat{x})$ non-hiperbolik.

Lemma 3. [22] Jika diasumsikan $F(1)>0$ dengan $\lambda_{1}, \lambda_{2}$ adalah akar-akar karakteristik dari $F(\lambda)=\lambda^{2}-$ Trace $\lambda+$ Det $=0$, maka:

(i) $\left|\lambda_{1}\right|<1$ dan $\left|\lambda_{2}\right|<1$ jika dan hanya jika $F(-1)>0$ dan Det $<1$.

(ii) $\left|\lambda_{1}\right|<1$ dan $\left|\lambda_{2}\right|>1$, atau $\left|\lambda_{1}\right|>1$ dan $\left|\lambda_{2}\right|<1$, jika dan hanya jika $F(-1)<0$.

(iii) $\left|\lambda_{1}\right|>1$ dan $\left|\lambda_{2}\right|>1$ jika dan hanya jika $F(-1)>0$ dan Det $>1$.

(iv) $\lambda_{1}=-1$ dan $\lambda_{2} \neq 1$ jika dan hanya jika $F(-1)=0$ dan Trace $\neq 0,2$.

(v) $\lambda_{1}$ dan $\lambda_{2}$ adalah bilangan kompleks dan $\left|\lambda_{1}\right|=\left|\lambda_{2}\right|$ jika dan hanya jika Trace ${ }^{2}-4$ Det $<$ 0 dan Det $=1$.

\subsection{Simulasi Numerik}

Simulasi numerik dalam artikel ini menggunakan aplikasi Anaconda versi 2019.3.0.0 dan Python versi 3.7.3150.0. Anaconda adalah distribusi open-source dari bahasa pemrograman Python dan $R$ yang digunakan untuk komputasi ilmiah.

\section{Hasil dan Pembahasan}

Model non-dimensional pada persamaan (3) didiskretisasi menggunakan skema Euler maju [20]. Model diskret dari model pada persamaan (3) adalah sebagai berikut:

$$
\begin{aligned}
& x_{n+1}=x_{n}+h\left[x_{n}\left(1-x_{n}\right)-\frac{m x_{n} y_{n}}{x_{n}+y_{n}}\right], \\
& y_{n+1}=y_{n}+h\left[s y_{n}\left(1-\frac{b y_{n}}{x_{n}+a}\right)\right],
\end{aligned}
$$


dengan $h>0$ adalah parameter yang menyatakan besar langkah dalam numerik (time-step). Berdasarkan Definisi 1, titik ekuilibrium dari model pada persamaan (4) diperoleh dengan menyelesaikan secara simultan kedua persamaan berikut:

$$
\begin{aligned}
& x=x+h\left[x(1-x)-\frac{m x y}{x+y}\right], \\
& y=y+h\left[s y\left(1-\frac{b y}{x+a}\right)\right],
\end{aligned}
$$

sehingga diperoleh empat titik ekuilibrium sebagai berikut:

$$
E_{0}=(0,0), \quad E_{1}=(1,0), \quad E_{2}=\left(0, \frac{a}{b}\right), \quad E_{3}=\left(x^{*}, y^{*}\right)
$$

dengan

$$
\begin{aligned}
x^{*} & =\frac{(b+1)-(a+m) \pm \sqrt{D_{x^{*}}}}{2(b+1)}, \\
y^{*} & =\frac{x^{*}+a}{b} \\
D_{x^{*}} & =\left(m-m_{1}\right)\left(m-m_{2}\right), \\
m_{1,2} & =(b+1)+a(1+2 b) \pm \sqrt{a b(a+1)(b+1) .}
\end{aligned}
$$

\subsection{Eksistensi Titik Ekuilibrium}

Berdasarkan Definisi 1, diturunkan Lemma 4 sebagai berikut.

Lemma 4. $\mathbb{R}_{+}^{2}=\{(x, y) \mid x \geq 0, y \geq 0,(x, y) \in \mathbb{R}\}$. Jika $E_{i}=(\hat{x}, \hat{y}), i=0,1,2,3$, adalah solusi dari persamaan (5), maka $E_{i}$ adalah titik ekuilibrium dari persamaan (4) jika dan hanya jika $E_{i} \in$ $\mathbb{R}_{+}^{2}$.

Bukti. Berdasarkan kondisi biologis, jumlah populasi selalu tak negatif, maka solusi dari persamaan (4) harus tak negatif.

Dari Lemma 4, diturunkan Teorema 5 berikut, yang menjelaskan eksistensi titik ekuilibrium dari model pada persamaan (4).

Teorema 5. Eksistensi titik ekuilibrium

(i) $E_{0}, E_{1}$, dan $E_{2}$ adalah titik ekuilibrium.

(ii) $E_{3}$ adalah titik ekuilibrium jika $D_{x^{*}} \geq 0$ dan

(ii.i) $0<(a+m)<(b+1)+\sqrt{D_{x^{*}}}$, atau

(ii.ii) $0<(a+m)+\sqrt{D_{x^{*}}}<(b+1)$.

$D_{x^{*}}>0$ memberikan dua titik interior, yaitu $x_{1}=x_{1}^{*}$ dan $x_{2}=x_{2}^{*}$, sedangkan $D_{x^{*}}=0$ hanya memberikan satu titik interior yaitu $x_{1}=x_{2}=x^{*}$. 


\section{Bukti.}

(i) $E_{0}, E_{1}, E_{2} \in \mathbb{R}_{+}^{2}$, maka $E_{0}, E_{1}, E_{2}$ adalah titik ekuilibrium persamaan (4).

(ii) Jika $D_{x^{*}}>0$, maka $\sqrt{D_{x^{*}}}>0$, sehingga syarat kepositifan titik ekuilibrium bergantung pada

(ii.i) $(b+1)-(a+m)+\sqrt{D_{x^{*}}}>0$, atau

(ii.ii) $(b+1)-(a+m)-\sqrt{D_{x^{*}}}>0$.

Diperoleh

$$
\begin{aligned}
& x_{1}^{*}=\frac{(b+1)-(a+m)+\sqrt{D_{x^{*}}}}{2(b+1)}>0 \\
& x_{2}^{*}=\frac{(b+1)-(a+m)-\sqrt{D_{x^{*}}}}{2(b+1)}>0
\end{aligned}
$$

Karena $x_{1}^{*}, x_{2}^{*}>0$, maka $y_{1}^{*}, y_{2}^{*}>0$, sehingga $E_{3} \in \mathbb{R}_{+}^{2}$. Akibatnya, $E_{3}$ adalah titik ekuilibrium persamaan (4). Jika $D_{x^{*}}=0$, maka $\sqrt{D_{x^{*}}}=0$, sehingga syarat kepositifan titik ekuilibrium bergantung pada $(b+1)-(a+m)>0$, sehingga diperoleh

$$
x_{1}^{*}=x_{2}^{*}=x^{*}=\frac{(b+1)-(a+m)}{2(b+1)}>0 .
$$

Karena $x^{*}>0$, maka $y^{*}>0$. Akibatnya $E_{3}$ adalah titik ekuilibrium persamaan (4).

\subsection{Kestabilan Titik Ekuilibrium}

Dinamika model pada persamaan (4) di sekitar $E_{i}, i=0,1,2,3$ dipelajari dengan melakukan pelinearan terhadap model pada persamaan (4). Matriks Jacobi dari model pada persamaan (4) di sekitar titik ekuilibrium diberikan oleh:

$$
J(\hat{x}, \hat{y})=\left[\begin{array}{cc}
1+h(1-2 \hat{x})-\frac{h m \hat{y}^{2}}{(\hat{x}+\hat{y})^{2}} & -\frac{h m \hat{x}^{2}}{(\hat{x}+\hat{y})^{2}} \\
\frac{h b s \hat{y}^{2}}{(\hat{x}+a)^{2}} & 1+h s-\frac{2 h b s \hat{y}}{\hat{x}+a}
\end{array}\right] .
$$

Berdasarkan Lemma 2 dan Lemma 3, diturunkan beberapa teorema berikut yang menjelaskan kestabilan model pada persamaan (4).

Teorema 6. $E_{0}$ selalu source.

Bukti. Dari $\operatorname{det}\left(J\left(E_{0}\right)-\lambda I\right)=0$, diperoleh $\lambda_{1}=1+h ; \lambda_{2}=1+h s$. Akibatnya, $\left|\lambda_{1}\right|>1$ dan $\left|\lambda_{2}\right|>1$. Sehingga berdasarkan Lemma 2(ii), $E_{0}$ tidak stabil (source). 
Teorema 7. $E_{1}$ memiliki tiga kondisi sebagai berikut.

(i) $E_{1}$ saddle jika $0<h<2$.

(ii) $E_{1}$ non-hiperbolikjika $h=2$.

(iii) $E_{1}$ source jika $h>2$.

Bukti. Dari $\operatorname{Det}\left(J\left(E_{1}\right)-\lambda I\right)=0$, diperoleh nilai eigen $\lambda_{1}=1-h$ dan $\lambda_{2}=1+h s$. Perhatikan bahwa nilai $h$ dan $s$ selalu positif sehingga $\left|\lambda_{2}\right|>1$. Jika $0<h<2$ maka $\left|\lambda_{1}\right|<1$, sehingga menurut Lemma 2(iii) titik ekuilibrium $E_{1}$ tidak stabil (saddle). Jika $h>2$ maka $\left|\lambda_{1}\right|>1$, sehingga menurut Lemma 2(ii) titik ekuilibrium $E_{1}$ tidak stabil (source). Selanjutnya jika $h=2$ maka $\left|\lambda_{1}\right|=1$, sehingga menurut Lemma 2(iv) titik ekuilibrium $E_{1}$ non-hiperbolik.

Teorema 8. $E_{2}$ memiliki empat kondisi sebagai berikut.

(i) $E_{2} \operatorname{sinkjika~} 1<m<1+\frac{2}{h}$ dan $0<h s<2$.

(ii) $E_{2}$ saddle jika

(ii.i) $1<m<1+\frac{2}{h}$ dan $h s>2$; atau

(ii.ii) $m>1+\frac{2}{h}$ atau $0<m<1$, dan $0<h s<2$.

(iii) $E_{2}$ source jika $m>1+\frac{2}{h}$ atau $0<m<1$; dan $h s>2$.

(iv) $E_{2}$ non-hiperbolikjika $m=1$ atau $m=1+\frac{2}{h}$; atau $h s=2$.

Bukti. Dari $\operatorname{Det}\left(J\left(E_{2}\right)-\lambda I\right)=0$, diperoleh nilai eigen $\lambda_{1}=1+h-h m$ dan $\lambda_{2}=1-h s$. Perhatikan bahwa $h, s$, dan $m$ selalu positif, maka kondisi-kondisi berikut akan berlaku: Jika $1<$ $m<1+\frac{2}{h}$, maka dengan operasi aljabar diperoleh $-1<1+h(1-m)<1$ atau $\left|\lambda_{1}\right|<1$ dan jika $m>1+\frac{2}{h}$ atau $0<m<1$ maka diperoleh $\left|\lambda_{1}\right|>1$. Jika $0<h s<2$, maka diperoleh $\left|\lambda_{2}\right|<$ 1 dan jika $h s>2$, maka $\left|\lambda_{2}\right|>1$. Selanjutnya jika $m=1$ atau $m=1+\frac{2}{h}$ atau $h s=$ 2 maka $\left|\lambda_{1}\right|=1$ atau $\left|\lambda_{2}\right|=1$. Dengan menggunakan Lemma 2(i)-(iv), Teorema 8 terbukti.

Teorema 9. Jika $x^{*}>\frac{\sqrt{a b m}-a}{b+1}$ maka $E_{3}$ memiliki tiga kondisi kestabilan yang bergantung pada parameter $h$ sebagai berikut:

(i) $E_{3}$ sink jika memenuhi salah satu kondisi berikut:

(i.i) $\Lambda \geq 0$ dan $0<h<h_{a}$; atau

(i.ii) $\Lambda<0$ dan $0<h<h_{b}$,

(ii) $E_{3}$ saddle jika $\Lambda>0$ dan $h_{a}<h<h_{c}$, 
(iii) $E_{3}$ source jika memenuhi salah satu kondisi berikut:

(iii.i) $\Lambda \geq 0$ dan $h>h_{c}$; atau

(iii.ii) $\Lambda<0$ dan $h>h_{b}$,

(iv) $E_{3}$ non-hiperbolik jika memenuhi salah satu kondisi berikut:

(iv.i) $\Lambda \geq 0$ dan $h=h_{a}$ atau $h=h_{c}$

(iv.ii) $\Lambda<0$ dan $h=h_{b}$,

dengan $h_{a}=\frac{\Lambda_{a}-\sqrt{\Lambda}}{\Lambda_{b}}, \quad h_{b}=\frac{\Lambda_{a}}{\Lambda_{b}}, \quad h_{c}=\frac{\Lambda_{a}+\sqrt{\Lambda}}{\Lambda_{b}}$, dan $\Lambda_{a}=x^{*}+s-\frac{m b x^{*}\left(x^{*}+a\right)}{\left((b+1) x^{*}+a\right)^{2}}, \quad \Lambda_{b}=s x^{*}-$ $\frac{s x^{*} m a b}{\left((b+1) x^{*}+a\right)^{2}}, \quad \Lambda=\Lambda_{a}^{2}-4 \Lambda_{b}$.

Bukti. Matriks Jacobi $J(\hat{x}, \hat{y})$ dihitung di titik eksistensi kedua populasi, $E_{3}=\left(x^{*}, y^{*}\right)$ diberikan oleh:

$$
J\left(E_{3}\right)=\left[\begin{array}{cc}
1+h\left(\frac{m b x^{*}\left(x^{*}+a\right)}{\left((b+1) x^{*}+a\right)^{2}}-x^{*}\right) & -\frac{h m b^{2} x^{* 2}}{\left((b+1) x^{*}+a\right)^{2}} \\
\frac{h s}{b} & 1-h s
\end{array}\right]
$$

Persamaan karakteristiknya dapat dituliskan: $\lambda^{2}-\operatorname{Trace}\left(J\left(E_{3}\right)\right) \lambda+\operatorname{Det}\left(J\left(E_{3}\right)\right)=0$, dengan $\operatorname{Trace}\left(J\left(E_{3}\right)\right)=2-h \Lambda_{a} \quad$ dan $\quad \operatorname{Det}\left(J\left(E_{3}\right)\right)=1-h \Lambda_{a}+h^{2} \Lambda_{b} . \quad$ Misalkan $\quad F(\lambda)=\lambda^{2}-$ $\operatorname{Trace}\left(J\left(E_{3}\right)\right) \lambda+\operatorname{Det}\left(J\left(E_{3}\right)\right), \quad$ maka $\quad F(1)=\Lambda_{b} h^{2}, \quad F(-1)=\Lambda_{b} h^{2}-2 \Lambda_{a} h+4, \quad$ dan $\operatorname{Det}\left(J\left(E_{3}\right)\right)=\Lambda_{b} h^{2}-\Lambda_{a} h+1$. Dari persamaan karakteristik diperoleh nilai eigen $\lambda_{1,2}=1-$ $\frac{h}{2} \Lambda_{a} \pm \frac{h}{2} \sqrt{\Lambda}$. Nilai dari $F(-1)$ dapat dinyatakan sebagai berikut:

(i) $F(-1)>0$ jika $\Lambda>0$ dan $0<h<h_{a}$ atau $h>h_{c}$.

(ii) $F(-1)=0$ dan $\operatorname{Trace}\left(J\left(E_{3}\right)\right) \neq 0,2$ jika $\Lambda>0$ dan $h=h_{a}$ atau $h=h_{c}$.

(iii) $F(-1)<0$ jika $\Lambda>0$ dan $h_{a}<h<h_{c}$.

Dari $\operatorname{Det}\left(J\left(E_{3}\right)\right)=1$ diperoleh $h_{b}$, dengan $h_{a}<h_{b}<h_{c}$.

Pada kasus $\Lambda<0$, mengakibatkan $\lambda_{1,2} \in \mathbb{C}$. Adapun nilai $\operatorname{Det}\left(J\left(E_{3}\right)\right)$ dinyatakan sebagai berikut:

(i) $\operatorname{Det}\left(J\left(E_{3}\right)\right)<1$ dan $\left|\lambda_{1,2}\right|<1$ jika $0<h<h_{b}$.

(ii) $\operatorname{Det}\left(J\left(E_{3}\right)\right)=1$ dan $\left|\lambda_{1,2}\right|=1$ jika $h=h_{b}$.

(iii) $\operatorname{Det}\left(J\left(E_{3}\right)\right)>1$ dan $\left|\lambda_{1,2}\right|>1$ jika $h>h_{b}$.

Dengan menggunakan Lemma 2 dan 3, maka Teorema 9 terbukti. 
Titik ekuilibrium $E_{0}$ dan $E_{1}$ merupakan titik yang tidak stabil secara struktural, sedangkan titik ekuilibrium $E_{2}$ dan $E_{3}$ merupakan titik yang stabil secara kondisional. Hal ini berarti bahwa kedua populasi tidak akan punah secara bersamaan, atau populasi predator tidak akan mungkin punah.

\subsection{Eksistensi Bifurkasi Periode Ganda dan Neimark-Sacker}

Selanjutnya akan ditunjukkan fenomena perubahan dinamika di sekitar titik ekuilibrium eksistensi kedua populasi yaitu bifurkasi periode ganda dan bifurkasi Neimark-Sacker. Bifurkasi periode ganda terjadi jika perubahan suatu nilai parameter mengakibatkan perubahan kestabilan titik ekuilibrium disertai munculnya solusi periodik dengan periode-2. Selanjutnya, bifurkasi NeimarkSacker terjadi jika perubahan suatu nilai parameter mengakibatkan perubahan kestabilan titik ekuilibrium disertai munculnya suatu limit-cycle yang mengisolasi titik ekuilibrium tersebut. Pada artikel ini ditunjukkan bahwa kedua bifurkasi ini terjadi pada titik eksistensi kedua populasi dengan menggerakkan nilai dari parameter $h$ atau time-stepnya.

Teorema 10. Titik ekuilibrium $E_{3}=\left(x^{*}, y^{*}\right)$ kehilangan kestabilannya:

(i) via bifurkasi periode ganda ketika $h$ melewati $h_{a}$ atau $h_{c}$,

(ii) via bifurkasi Neimark-Sacker ketika $h$ melewati $h_{b}$.

Bukti. Kajian lengkap tentang teori bifurkasi dapat dilihat pada Elaydi [20]. Berdasarkan Teorema 9, $E_{3}$ non-hiperbolik pada saat $\Lambda \geq 0$ dan $h=h_{a}$ atau $h=h_{c}$; dan $\Lambda<0 \operatorname{dan} h=h_{b}$. Jika $\Lambda \geq 0$ dan $h=h_{a}$ atau $h=h_{c}$ maka salah satu nilai eigen bernilai -1. Akibatnya solusi periode-2 muncul ketika $h$ melewati $h=h_{a}$ atau $h=h_{c}$ sehingga terjadi bifurkasi periode ganda. Pada saat $\Lambda<0$ dan $h=h_{b}$, terdapat sepasang nilai eigen kompleks dengan modulusnya bernilai 1 . Akibatnya limit-cycle muncul ketika $h$ melewati $h_{b}$. Dengan demikian terjadi bifurkasi NeimarkSacker.

\subsection{Simulasi Numerik}

Pada tahapan ini diberikan beberapa simulasi numerik yang bersesuaian dengan hasil analisis yang dipaparkan sebelumnya. Simulasi numerik diawali dengan menunjukkan kestabilan lokal untuk $E_{2}$ dan $E_{3}$, dan dilanjutkan dengan memberikan simulasi eksistensi dari bifurkasi periode ganda dan Neimark-Sacker. Parameter yang digunakan dipilih berdasarkan kondisi yang diberikan pada hasil analisis sebelumnya dikarenakan tidak adanya data rill yang bersesuaian dengan model. Oleh karena itu, diberikan nilai parameter sebagai berikut.

$$
m=1.1, \quad s=0.9, \quad b=0.5, \quad a=0.1, \quad h=0.1
$$

Dengan menggunakan nilai parameter (8) diperoleh titik ekuilibrium $E_{2}=(0,2)$ yang stabil asimtotik lokal, lihat Gambar 1. Hal ini menunjukkan bahwa populasi prey akan punah dan eksistensi dari predator tetap dipertahankan jika nilai awal dari kedua populasi cukup dekat 
dengan titik ekuilibrium tersebut. Kondisi ini bersesuaian dengan asumsi sebelumnya bahwa predator memiliki alternatif makanan lain selain prey. Ketika $m$ diturunkan menjadi 0.3 , titik ekuilibrium $E_{2}$ berubah menjadi tidak stabil yang disertai dengan munculnya titik ekuilibrium tunggal $E_{3}$ yang stabil asimtotik lokal seperti yang ditunjukkan oleh Gambar 2. Hal ini menunjukkan bahwa jika laju pemangsaan prey oleh predator diturunkan maka populasi prey dan predator akan terjaga eksistensinya.

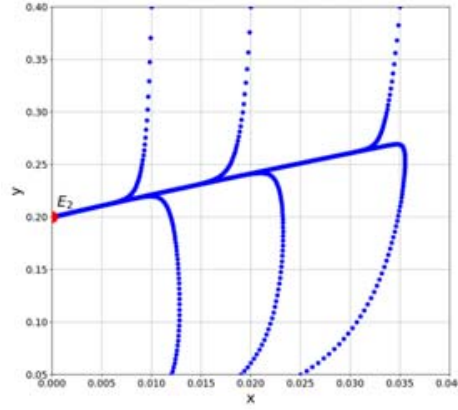

(a)

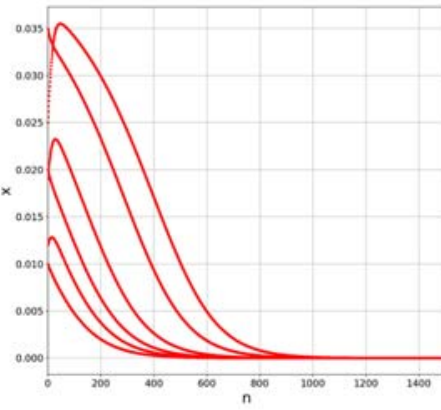

(b)

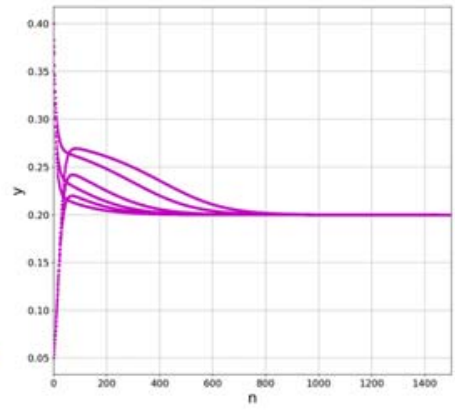

(c)

Gambar 1. Simulasi numerik model pada persamaan (4) dengan nilai parameter pada persamaan (8) (a) Potret fase disekitar $E_{2}$ (b) dan (c) Simulasi deret waktu $x$ dan $y$ terhadap $n$.

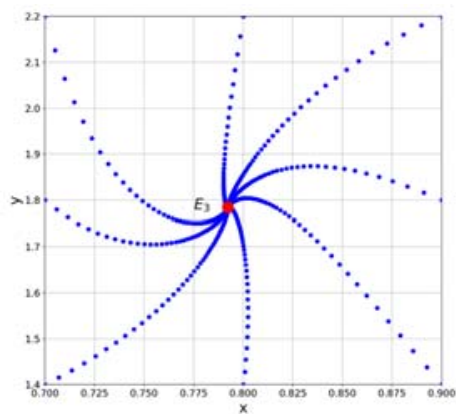

(a)

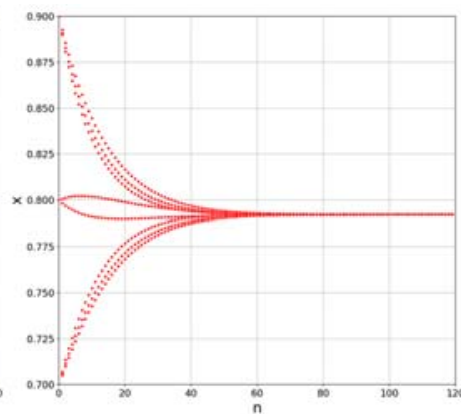

(b)

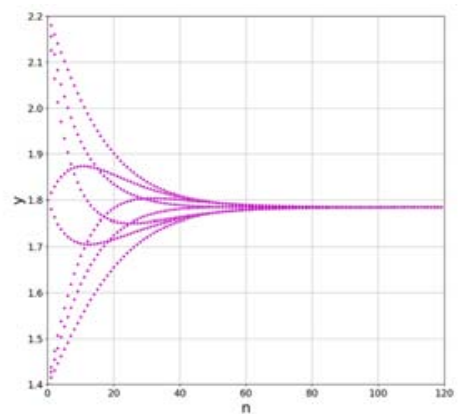

(c)

Gambar 2. Simulasi numerik model pada persamaan (4) dengan nilai parameter pada persamaan (8) dan $m=0.3$ (a) Potret fase disekitar $E_{2}$ (b) dan (c) Simulasi deret waktu $x$ dan $y$ terhadap $n$

Untuk menunjukkan eksistensi dari bifurkasi periode ganda, dipilih nilai parameter seperti pada persamaan (8) dengan mengganti nilai $m=0.3$, dan $s=0.33$. Selanjutnya dilakukan iterasi sebanyak 5000 kali dan di plot 200 titik terakhir. Proses ini dilakukan untuk $2.9 \leq h \leq 3.4$ dengan tujuan untuk melihat konvergensi dari solusi dengan variasi nilai $h$, sehingga diperoleh diagram bifurkasi seperti pada Gambar 3. 

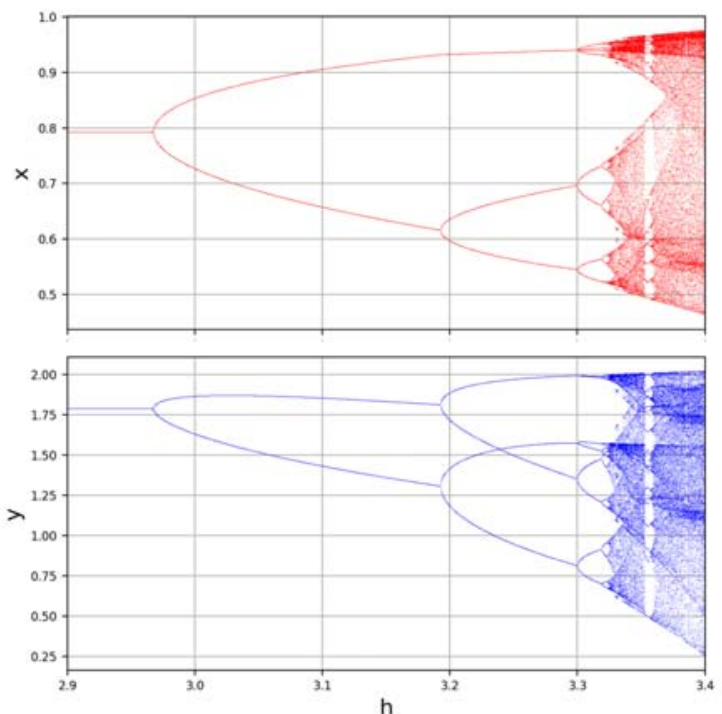

Gambar 3. Diagram bifurkasi periode ganda pada model pada persamaan (4) dengan nilai parameter pada persamaan (8), $m=0.3$, dan $s=0.33$

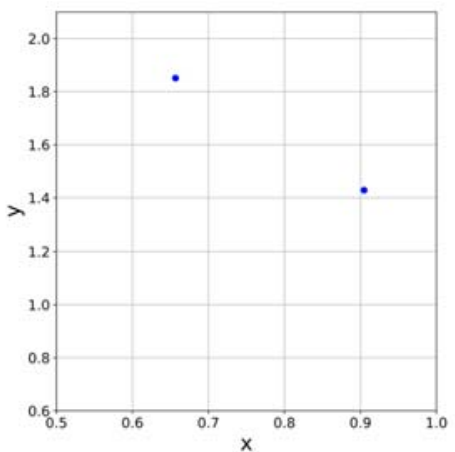

(a) $h=3.1$

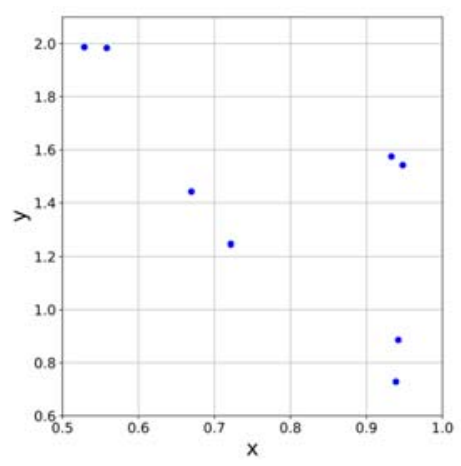

(c) $h=3.31$

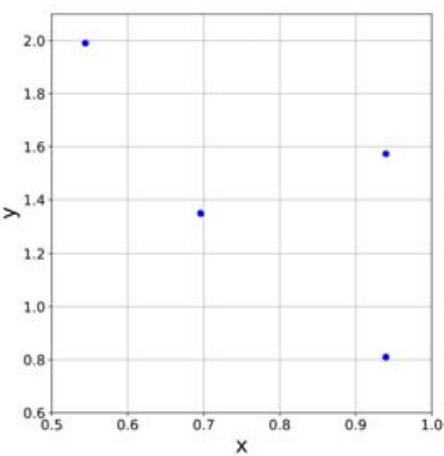

(b) $h=3.3$

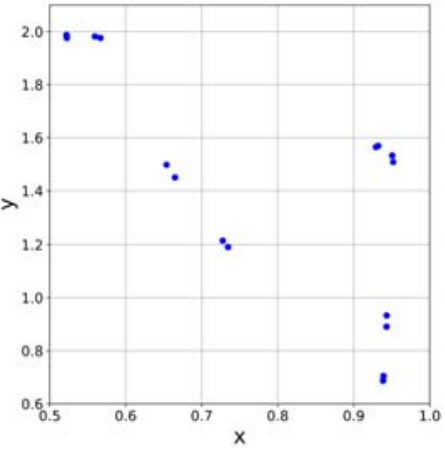

(d) $h=3.32$

Gambar 4. Solusi periodik pada model pada persamaan (4) dengan nilai parameter pada persamaan (8), $m=0.3$, dan $s=0.33$ 

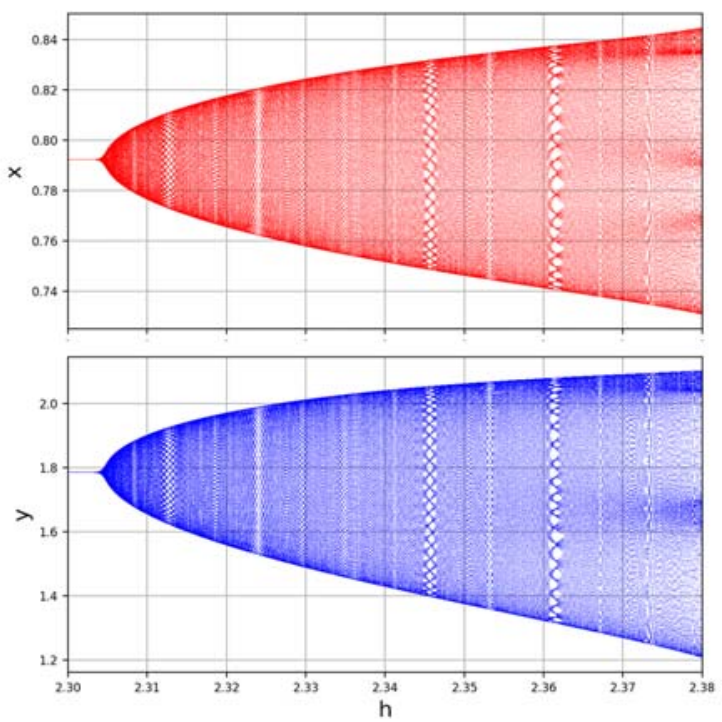

Gambar 5. Diagram bifurkasi Neimark-Sacker pada model pada persamaan (4) dengan nilai parameter pada persamaan (8) dan $m=0.3$

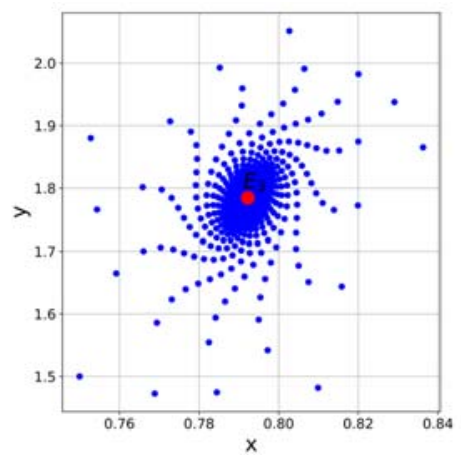

(a) $h=2.3$

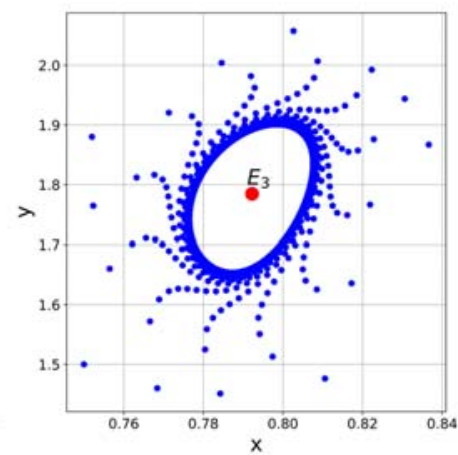

(b) $h=2.31$

Gambar 6. Potret fase model pada persamaan (4) dengan nilai parameter pada persamaan

(8) dan $m=0.3$

Perhatikan bahwa solusi yang pada awalnya konvergen ke titik ekuilibrium $E_{3}$, kehilangan kestabilannya via bifurkasi periode ganda dan menuju ke solusi periode-2. Dari Gambar 3 juga diperlihatkan munculnya solusi periodik dengan berbagai periode dari solusi. Untuk menunjukkannya, dipilih beberapa nilai $h$. Pada saat $h=3.1$ solusi konvergen ke solusi periode2, lihat Gambar 4(a). Nilai $h$ dinaikkan menjadi 3.3 sehingga muncul solusi periode-4 yang stabil seperti pada Gambar 4(b). Ketika $h$ menjadi 3.31, solusi konvergen ke solusi periode- 8 yang ditunjukkan oleh Gambar 4(c), dan simulasi untuk solusi periodik diakhiri dengan memilih $h=$ 3.32 dimana muncul solusi periode-16 seperti pada Gambar 4(d). Secara biologis, hal ini 
menunjukkan bahwa meskipun titik ekuilibrium $E_{3}$ tidak stabil, namun eksistensi dari kedua populasi terjaga secara periodik.

Simulasi numerik ini diakhiri dengan menunjukkan eksistensi dari bifurkasi NeimarkSacker. Dengan memilih nilai parameter pada persamaan (8) dan $m=0.3$, serta menggerakkan nilai $h$ diperoleh diagram bifurkasi seperti Gambar 5. Solusi yang pada awalnya konvergen ke titik ekuilibrium $E_{3}$ kehilangan kestabilannya via bifurkasi Neimark-Sacker yang ditandai munculnya limit-cycle yang mengisolasi titik ekuilibriumnya. Pada saat $h=2.3$, solusi masih konvergen ke $E_{3}$ yang ditunjukkan oleh Gambar 6(a), dan ketika $h=2.31$, titik ekuilibrium $E_{3}$ menjadi tidak stabil disertai munculnya limit-cycle yang mengisolasi titik ekuilibrium tersebut, lihat Gambar 6(b). Meskipun titik ekuilibrium $E_{3}$ kehilangan kestabilannya, namun solusi bergerak secara periodik di sekitar limit-cycle. Secara biologis, hal ini berarti bahwa dengan kondisi awal kepadatan kedua populasi yang cukup dekat dengan titik ekuilibrium $E_{3}$, eksistensi kedua populasi tetap terjaga.

\section{Simpulan}

Model pada persamaan (4) merepresentasikan interaksi antara dua spesies dengan hubungan mangsa-pemangsa dimana prey dan predator masing-masing tumbuh secara logistik dengan daya dukung prey bergantung kepada lingkungannya dan daya dukung predator adalah kepadatan prey dan mangsa alternatifnya. Dari hasil analisis ditunjukkan bahwa kepunahan dari predator tidak akan pernah tercapai, sedangkan kepunahan dari prey bisa tercapai dengan kondisi biologis tertentu. Fenomena menarik juga ditunjukkan secara biologis di sekitar titik kesetimbangan dimana eksistensi dari kedua populasi terjaga meskipun titik interior kehilangan kestabilannya via bifurkasi periode-ganda dan Neimark-Sacker. Kepadatan populasi bergerak secara periodik di sekitar titik interior.

Meskipun dinamika dari model ini telah dibahas cukup lengkap, namun ada satu hal menarik yang tidak dieksplorasi pada artikel ini. Dari simulasi yang ditunjukkan pada Gambar 3, dapat dilihat bahwa terdapat kemungkinan munculnya solusi periode-3, dimana menurut Elaydi [20] merupakan salah satu indikator adanya strange-attractor yang memicu terjadinya chaos.

\section{Ucapan Terima Kasih}

Terimakasih kepada Bapak Hasan S. Panigoro atas masukan dan sarannya dalam penelitian dan penulisan artikel ini. 


\section{Daftar Pustaka}

[1] A. A. Berryman, "The Orgins and Evolution of Predator-Prey Theory," Ecology, vol. 73, no. 5, pp. 1530-1535, Oct. 1992, doi: 10.2307/1940005.

[2] J. D. Murray, Mathematical Biology: An Introduction, 3rd ed. New York, NY: Springer New York, 2002.

[3] P. H. Leslie, "Some Further Notes on the Use of Matrices in Population Mathematics," Biometrika, vol. 35, no. 3-4, pp. 213-245, 1948, doi: 10.1093/biomet/35.3-4.213.

[4] M. A. Aziz-Alaoui and M. Daher Okiye, "Boundedness and global stability for a predatorprey model with modified Leslie-Gower and Holling-type II schemes," Appl. Math. Lett., vol. 16, no. 7, pp. 1069-1075, 2003, doi: 10.1016/S0893-9659(03)90096-6.

[5] C. S. Holling, "Some Characteristics of Simple Types of Predation and Parasitism," Can. Entomol., vol. 91, no. 07, pp. 385-398, 1959, doi: 10.4039/Ent91385-7.

[6] R. Arditi and L. R. Ginzburg, "Coupling in predator-prey dynamics: Ratio-Dependence," J. Theor. Biol., vol. 139, no. 3, pp. 311-326, 1989, doi: 10.1016/S0022-5193(89)80211-5.

[7] I. Hanski, "The functional response of predators: Worries about scale," Trends Ecol. Evol., vol. 6, no. 5, pp. 141-142, May 1991, doi: 10.1016/0169-5347(91)90052-Y.

[8] M. J. Bishop, B. P. Kelaher, M. P. L. Smith, P. H. York, and D. J. Booth, "Ratio-dependent response of a temperate Australian estuarine system to sustained nitrogen loading," Oecologia, vol. 149, no. 4, pp. 701-708, Oct. 2006, doi: 10.1007/s00442-006-0481-5.

[9] A. Suryanto, I. Darti, H. S. Panigoro, and A. Kilicman, "A Fractional-Order Predator-Prey Model with Ratio-Dependent Functional Response and Linear Harvesting," Mathematics, vol. 7, no. 11, p. 1100, Nov. 2019, doi: 10.3390/math7111100.

[10] N. Hasan, R. Resmawan, and E. Rahmi, "Analisis Kestabilan Model Eko-Epidemiologi dengan Pemanenan Konstan pada Predator,” J. Mat. Stat. dan Komputasi, vol. 16, no. 2, p. 121, Dec. 2019, doi: 10.20956/jmsk.v16i2.7317.

[11] H. S. Panigoro, “Analisis Dinamik Sistem Predator-Prey Model Leslie-Gower dengan Pemanenan Secara Konstan terhadap Predator,” EULER, vol. 2, no. 1, pp. 1-12, 2014.

[12] P. D. Ernawati and I. Darti, "Stability analysis of the Euler discretization for the harvesting Leslie-Gower predator-prey model,” Int. J. Pure Apllied Math., vol. 105, no. 2, pp. 213 221, Nov. 2015, doi: 10.12732/ijpam.v105i2.8.

[13] H. S. Panigoro, E. Rahmi, N. Achmad, and S. L. Mahmud, "The Influence of Additive Allee Effect and Periodic Harvesting to the Dynamics of Leslie-Gower Predator-Prey Model," Jambura J. Math., vol. 2, no. 2, pp. 87-96, Mar. 2020, doi: 10.34312/jjom.v2i2.4566. 
[14] H. S. Panigoro and D. Savitri, "Bifurkasi Hopf pada Model Lotka-Volterra Orde-Fraksional dengan Efek Allee Aditif pada Predator,” Jambura J. Biomath., vol. 1, no. 1, pp. 16-24, Jun. 2020, doi: 10.34312/jjbm.v1i1.6908.

[15] H. S. Panigoro, A. Suryanto, W. M. Kusumawinahyu, and I. Darti, "Dynamics of a Fractional-Order Predator-Prey Model with Infectious Diseases in Prey," Commun. Biomath. Sci., vol. 2, no. 2, pp. 105-117, 2019, doi: 10.5614/cbms.2019.2.2.4.

[16] M. Renisagayaraj, A. G. M. Selvam, and M. Meganathan, "Dynamics in a Discrete PreyPredator System,” Int. J. Eng. Res. Dev., vol. 6, no. 5, pp. 1-5, 2013.

[17] M. Zhao, Z. Xuan, and C. Li, "Dynamics of a discrete-time predator-prey system," Adv. Differ. Equations, vol. 2016, no. 1, p. 191, Dec. 2016, doi: 10.1186/s13662-016-0903-6.

[18] L. Edelstein-Keshet, "Mathematical models in biology," in Classics in applied mathematics, 2005.

[19] H. S. Panigoro and E. Rahmi, "Modifikasi sistem predator-prey: dinamika model LeslieGower dengan daya dukung yang tumbuh logistik," in SEMIRATA MIPAnet, 2017, pp. 94 103.

[20] S. N. Elaydi, Discrete Chaos: With Applications in Science and Engineering, 2nd ed., vol. 2007. San Antonio, Texas: Chapman \& Hall/ CRC, 2007.

[21] M. A. M. Abdelaziz, A. I. Ismail, F. A. Abdullah, and M. H. Mohd, "Bifurcations and chaos in a discrete SI epidemic model with fractional order," Adv. Differ. Equations, vol. 2018, no. 1, p. 44, Dec. 2018, doi: 10.1186/s13662-018-1481-6.

[22] L. G. Yuan and Q. G. Yang, "Bifurcation, invariant curve and hybrid control in a discretetime predator-prey system,” Appl. Math. Model., vol. 39, no. 8, pp. 2345-2362, Apr. 2015, doi: 10.1016/j.apm.2014.10.040. 